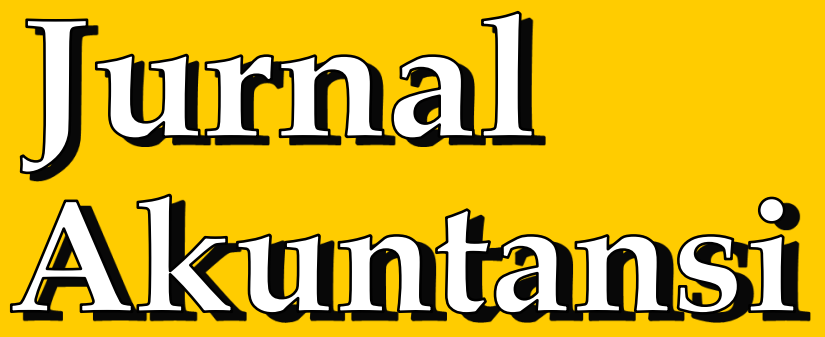

\title{
dan IKenangan
}

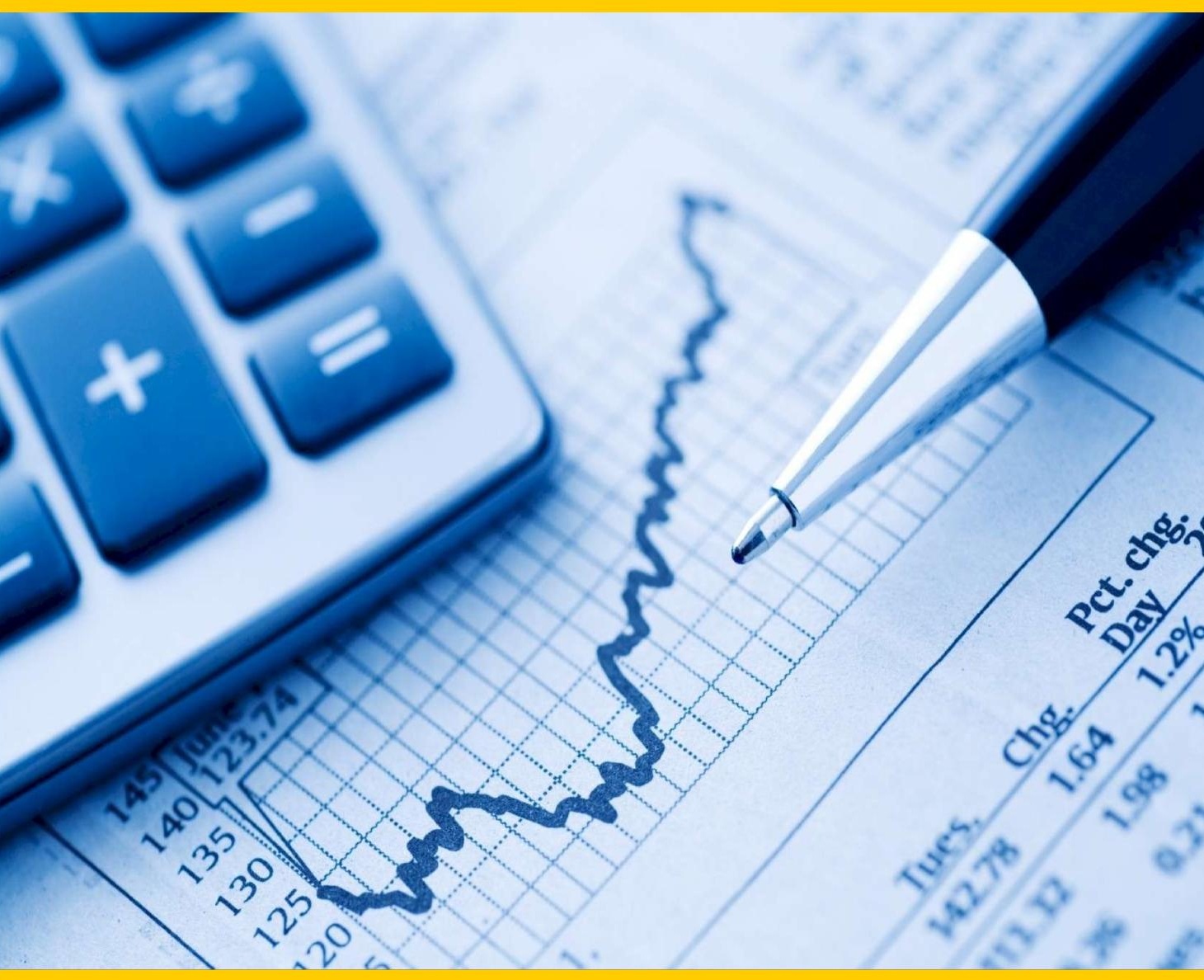

Diterbitkan oleh:

Program Studi Akuntansi

Fakultas Ekonomi dan Bisnis, Universitas Malikussaleh 


\section{EDITOR IN CHIEF}

Indrayani, SE., M.Si., Ak., CA

Universitas Malikussaleh

\section{MANAGING EDITOR}

Nur Afni Yunita, SE., M.Si

Universitas Malikussaleh

\section{ASSOCIATED EDITOR}

Pasca Dwi Putra, SE., M.Si

Universitas Negeri Medan

Yani Prihatina Eka Furda, SE., M.Si

Universitas Iskandar Muda

Budianto, SE., M.Si

Universitas Teuku Umar

Lakharis Inuzula, SE., M.Si., Ak Universitas Islam Kebangsaan

Indonesia

Isra Maulina, SE., M.Si

IAIN Lhokseumawe

\section{COPY EDITORS}

Muhammad Yusra, SE., M.Si

Universitas Malikussaleh

\section{LAYOUT EDITORS}

Dy Ilham Satria, SE., M.Si

Universitas Malikussaleh

Nurhasanah, SE., M.Si., Ak

Universitas Malikussaleh

PROOFREADER \& LANGUAGE EDITORS

Marina, S.Pdi., M.Ed

Universitas Malikussaleh

Hanif, S.Pd., M.Pd

Universitas Malikussaleh

\section{REVIEWER}

Dr. Jumadil Saputra (Universitas Malaysia Terengganu)

Dr. Jufri Darma, SE., M.Si., Ak., CA (Universitas Negeri Medan)

Dr. Ruhul Fitrios, SE., M.SI (Universitas Riau)

Dr. Husaini, SE., M.Si., AK., CA (Universitas Bengkulu)

Dr. Fazli Syam BZ., SE., M.Si., Ak., CA (Universitas Syiah Kuala)

Dr. Muhammad Arfan, SE., M.Si., Ak., CA (Universitas Syiah Kuala)

Dr. Lilis Maryasih, SE., M.Si., Ak., CA (Universitas Syiah Kuala)

Dr. Elvira Luthan, SE., M.Si., Ak., CA (Universitas Andalas Padang)

Dr. Wahyudin Nor, SE., M.Si., Ak., CA, CSRS, CSRA (Universitas Lambung Mangkurat)

Dr. Murhaban, SE., M.Si., Ak., CA (Universitas Malikussaleh)

Dr. Hendra Raza, SE., M.Si., Ak., CA (Universitas Malikussaleh)

Dr. Muammar Khaddafi, SE., M.Si., Ak., CA (Universitas

Malikussaleh)

Dr. Rita Meutia, SE., M.Si., Ak., CA (Universitas Malikussaleh)

Dr. Nazaina, SE., M.Si., Ak., CA (Universitas Malikussaleh)

Dr. Hendra Raza, SE., M.Si., Ak., CA (Universitas Malikussaleh)

Dr. Hilmi, SE., M.Si., Ak., CA (Universitas Malikussaleh)

Dr. Iswadi, SE., M.Si., Ak., CA (Universitas Malikussaleh)

Dr. M. Haykal , SE., M.Si., Ak., CA (Universitas Malikussaleh) 


\section{Daftar Isi}

Analisis Penyelesaian Tindak Lanjut Hasil Pemeriksaan BPK Pada 01-16 Pemeriksaan Kinerja Atas Kegiatan APIP Inspektorat Kabupaten Barito Timur Josmar Lambok Banjar Nahor, Ade Adriani, Wahyudin Nor DOI: https://doi.org/10.29103/jak.v9i1.3447

Analisis Perbedaan Komitmen Profesional Dan Sosialisasi Antisipatif 17-28 Mahasiswa Bidikmisi Dan Non-Bidikmisi Pada Hubungannya Dengan Whistleblowing (Studi Kasus Pada Mahasiswa Akuntansi Universitas Malikussaleh)

Muhammad Yusra, Nur Afni Yunit1, Nurhasanah DOI: https://doi.org/10.29103/jak.v9i1.3564

Struktur Kepemilikan Manajerial, Struktur Kepemilikan

Institusional, Dan Ukuran Perusahaan Terhadap Kinerja Perusahaan Dan Dampaknya Terhadap Manajemen Laba Pada Perusahaan

Sektor Pertambangan Batubara Pada Tahun 2017-2019

Rina Malahayati

DOI: https://doi.org/10.29103/jak.v9i21.3551

Pengaruh Pengalaman Auditor, Skeptisisme Profesional Dan Tekanan $37-44$ Waktu Terhadap Pendeteksian Kecurangan Di Perwakilan Bpkp Provinsi Bali

Anak Agung Putu Gede Bagus Arie Susandya, Ni Nyoman Ayu Suryandari DOI: https://doi.org/10.29103/jak.v9i1.3579

Pengaruh Kompetensi, Profesionalisme, dan Etika Auditor Terhadap 45-56 Kualitas Audit (Studi Pada Inspektorat Provinsi Bengkulu) Lismawati, Novita Sari, Mifta Ismalia DOI: https://doi.org/10.29103/jak.v9i1.3649

Pengaruh Pengungkapan Identitas Etis Islam, Agency Cost Dan $57-68$ Intellectual Capital Terhadap Kinerja Keuangan (Studi Pada Bank Umum Syariah Yang Terdaftar Di Otoritas Jasa Keuangan Periode 2016-2018)

Mursidah, Yunina, Meutia Zahara

DOI: https://doi.org/10.29103/jak.v9i1.3726 